\title{
On the Validity of Minimum Magnetizability Principle in Chemical Reactions
}

\author{
Hiteshi Tandon, ${ }^{1, *}$ Tanmoy Chakraborty ${ }^{2, *}$ and Vandana Suhag ${ }^{3}$ \\ ${ }^{1}$ Department of Chemistry, Manipal University Jaipur, Jaipur 303007, India \\ ${ }^{2}$ Department of Chemistry and Biochemistry, School of Basic Sciences and Research, Sharda University, \\ Greater Noida 201310, India \\ ${ }^{3}$ Department of Applied Sciences, BML Munjal University, Gurugram 122413, India
}

*Corresponding author: E-mail: tanmoychem@gmail.com, tanmoy.chakraborty@sharda.ac.in (T. Chakraborty) hiteshitandon@yahoo.co.in(H.Tandon)

Received: $10-23-2020$

\begin{abstract}
A new principle known as Minimum Magnetizability Principle has recently been introduced in the context of Density Functional Theory. In order to validate this principle, changes in the magnetizability $(\Delta \xi)$ and its cube-root $\left(\Delta \xi^{1 / 3}\right)$ are computed at B3LYP/LanL2DZ level of theory for some elementary chemical reactions. The principle is found to be valid for $77 \%$ of reactions under study. It is observed that the molecules with the lowest sum of $\xi$ or $\xi^{1 / 3}$ are generally the most stable. The principle fails to work in the presence of hard species. A comparative study is also made with change in hardness $(\Delta \eta)$, electrophilicity index $(\Delta \omega)$, polarizability $(\Delta \alpha)$ and their cube-roots $\left(\Delta \eta^{1 / 3}, \Delta \omega^{1 / 3}, \Delta \alpha^{1 / 3}\right)$. It is observed that the Minimum Magnetizability Principle is nearly as reliable as Minimum Electrophilicity Principle. It appears that this principle could be helpful in predicting the direction of diverse reactions as well as stable geometrical arrangements.
\end{abstract}

Keywords: Density Functional Calculations; Magnetic Properties; Maximum Hardness Principle (MHP); Minimum Electrophilicity Principle (MEP); Minimum Polarizability Principle (MPP)

\section{Introduction}

Theoretical Chemistry aims at unearthing novel concepts and principles to explain a broad range of chemical reactions. The most common questions that arise for any kind of reaction are about the pace and extent of the reaction. It is logical that thermodynamic data is required for providing an answer to the latter. Constructively, numerous reactivity descriptors have been established within the context of Conceptual Density Functional Theory (CDFT). ${ }^{1}$ These descriptors play a significant role in studying the changes taking place in a reacting system. This ultimately helps in understanding the reactivity and stability patterns of the reactants and products in a chemical reaction. Some of these descriptors are hardness $(\eta),{ }^{2}$ electrophilicity index $(\omega),{ }^{3-6}$ and polarizability $(\alpha)^{7}$ whose definitions are given as follows:

$$
\eta=\left(\frac{\partial^{2} E}{\partial N^{2}}\right)_{v(r)}=\frac{\left(E_{L}-E_{H}\right)}{2}
$$

$$
\begin{aligned}
& \omega=\frac{\mu^{2}}{2 \eta}=\left\{\frac{\left[\left(E_{L}+E_{H}\right) / 2\right]^{2}}{2\left[\left(E_{L}-E_{H}\right) / 2\right]}\right\} \\
& \alpha=-\left(\frac{\partial^{2} E(\epsilon)}{\partial \epsilon^{2}}\right)_{(\epsilon=0)}
\end{aligned}
$$

Here $E$ refers to the system's energy with respect to the number of electrons $N$ at fixed external potential $v(r)$. $E_{\mathrm{L}}$ and $E_{\mathrm{H}}$ stand for the frontier orbital energies while $\mu$ is the chemical potential. $\in$ represents the external electric field. Another reactivity descriptor is magnetizability $(\xi)$ which is defined as the linear response of an atom, molecule or ion's electron cloud towards an external magnetic field. ${ }^{8}$ It is expressed as:

$$
\xi=-\left(\frac{\partial^{2} E(B)}{\partial B^{2}}\right)_{(B=0)}
$$

where $B$ signifies the external magnetic field. It is an important descriptor to study chemical reactivity, stability and aromaticity of different atoms and molecules. ${ }^{9-14}$ Dynamics of reactions have also been studied for molecules in 
confinement using magnetizability. ${ }^{15}$ This property is of multidisciplinary interest and has extensive applications in the realm of physical, biological, engineering and materials science such as organic electronics, ${ }^{16}$ magnetically labelled cells, drugs and therapeutic agents, ${ }^{17}$ magnetic flux concentrators, ${ }^{18}$ magnetizable elastomers, ${ }^{19}$ bionanocomposites ${ }^{20}$ magnetic immunoadsorbents, ${ }^{21}$ magnetic nanoparticles/ nanofibres ${ }^{17}$ and so on besides its use in general chemical science. Looking at the widespread relevance of this property, it is believed that further exploration on its behaviour and characteristics will assist in strengthening the fundamentals of the concept, thereby supporting its efficient and appropriate use in various applications.

Based on above mentioned concepts and descriptors, some principles have been formulated in the framework of Density Functional Theory (DFT). The Maximum Hardness Principle (MHP) states that "there seems to be a rule of nature that molecules arrange themselves so as to be as hard as possible".22 Another principle known as Minimum Polarizability Principle (MPP) proposes that "the natural direction of evolution of any system is toward a state of mimimum polarizability". 23 A Minimum Electrophilicity Principle (MEP) was also suggested according to which "the natural direction of a chemical reaction is toward a state of minimum electrophilicity". ${ }^{24}$ Numerous efforts have been made to verify the reliability of these principles in diverse reactions/species. ${ }^{25,26}$ However, a breakdown of these principles was also observed in many cases. ${ }^{27-30}$

Recently, one more principle, known as the Minimum Magnetizability Principle (MMP), has been introduced in the context of DFT based on the descriptor magnetizability. According to this principle, "a stable configuration/conformation of a molecule or a favourable chemical process is associated with a minimum value of the magnetizability". ${ }^{31}$ In case of MMP, unlike other principles, no study has been performed yet to test the validity of this principle for chemical reactions. As understandable, operational efficiency of a principle can only be determined through performing a validation procedure. Accordingly, in order to employ MMP for practical purposes, it is necessary to carry out its verification based on some criteria. Thus, in the present study we have tried to assess the potential and accuracy of this principle for the first time with respect to some chemical reactions.

\section{Method of Computation}

In order to verify the validity of Minimum Magnetizability Principle along with comparing it to the other principles, viz. MHP, MPP and MEP, 30 elementary reactions are selected. Geometry optimizations for each of the reactant and product molecules have been performed at B3LYP/LanL2DZ level of theory. This is a very common and powerful method employed in computations and incorporates the correlation effects. Hence, the energy values of the HOMO (Highest Occupied Molecular Orbital) $\left(E_{\mathrm{H}}\right)$ and the LUMO (Lowest Unoccupied Molecular Orbital) $\left(E_{\mathrm{L}}\right)$ as well as molecular polarizability are obtained for the molecules. The canonical molecular orbitals differ from Kohn-Sham orbitals, nevertheless their values for orbital energy are found to be comparable. ${ }^{32}$ As a result, the operational forms of hardness and electrophilicity presented in Eq. (1) and Eq. (2) are used to calculate the value for hardness and electrophilicity. Further, magnetizabilities are computed using the Keith and Bader's method ${ }^{33}$ at the same level of theory. All computations have been performed on the computational software Gaussian 03. ${ }^{34}$

Next, in view of the MMP, the reaction is favoured only when the products to be formed are of lower magnetizability than the reactants. Thus, for a chemical reaction $\left(A_{j}\right)$, represented as $\Sigma a_{j} A_{j}=0$ in a condensed form, where $a_{j}$ corresponds to the stoichiometry of the $j^{\text {th }}$ atom/molecule, the corresponding deviation in a parameter $X$ through the reaction can be clearly expressed as:

$$
\Delta X=\sum_{j} a_{j} X_{j}
$$

In Eq. (5), $X_{j}$ refers to the value of $X$ for the $j^{\text {th }}$ atom/ molecule in the given chemical reaction. It follows that the direction in which the chemical reaction will progress may be indicated by the sign of $\Delta X$. Thus in accordance with MMP, it appears that the sign of $\Delta \xi$ provides an evidence of the direction in which any reaction proceeds. Hence, we have calculated the change in parameter $X, v i z$. hardness $(\Delta \eta)$, electrophilicity $(\Delta \omega)$, polarizability $(\Delta \alpha)$, and magnetizability $(\Delta \xi)$, for the selected reactions using Eq. (5). Change in the cube-roots of hardness $\left(\Delta \eta^{1 / 3}\right)$, electrophilicity $\left(\Delta \omega^{1 / 3}\right)$, polarizability $\left(\Delta \alpha^{1 / 3}\right)$ and magnetizability $\left(\Delta \xi^{1 / 3}\right)$ have also been calculated. Enthalpy change $\left(\Delta_{\mathrm{f}} H^{0}\right)$ for each molecule is also calculated using the atomization energy data from reference [35].

\section{Results and Discussion}

The study presents validity of Minimum Magnetizability Principle using chosen 30 elementary reactions. A comparison of the results is also presented with respect to the other principles, viz. MHP, MPP and MEP. It must be noted that several of the chosen reactions are hypothetical. All the reactions are exothermic signifying that the products are thermodynamically stable. Also, the variation of chosen parameters is not considered along the reaction path, but merely the overall change in these parameters in the chemical reaction is evaluated, which can be simply computed as long the geometry can be. Further, it should be noted that the reactants in reaction 14 are the same as in reaction 19 , however the type of products formed in both are different.

The computed values for hardness $(\eta)$, electrophilicity index $(\omega)$, polarizability $(\alpha)$, magnetizability $(\xi)$ and 
$\operatorname{HOMO}\left(E_{\mathrm{H}}\right)$ and LUMO $\left(E_{\mathrm{L}}\right)$ energy, along with magnetizability $\left(\xi_{\mathrm{T}}\right)$ data from the literature, ${ }^{36}$ for all the reactants and products of the selected reactions are presented in Table 1. A comparison of computed magnetizabilities $(\xi)$ with tabulated magnetizabilities ${ }^{36}\left(\xi_{\mathrm{T}}\right)$ reveals a good similarity between the two datasets $\left(R^{2}=0.997\right)$ indicating the efficacy of our computed data. The changes in enthalpy $\left(\Delta_{\mathrm{f}} H^{0}\right)$ and in parameter values with their reaction are provided in Table 2. As mentioned above, the formation of products is only favoured when the magnetizability of reactant is more than that of the products to be formed according to the MMP. Moreover the sign of $\Delta \xi$ gives an idea of the direction in which any reaction proceeds. A close look at Table 2 reveals that Minimum Magnetizability Principle is valid for chemical reactions since $\Delta \xi<0$ for various reactions. Further, $\Delta \xi$ is negative in numerous cases which undoubtedly demonstrates that $\Delta \xi$ provides a sign for the most stable species. Thus, the favoured direction of a chemical reaction is towards less magnetizability. When the stability of products is more than the reactants, change in enthalpy is less than zero $\left(\Delta_{\mathrm{f}} H^{0}<0\right)$. This condition is also clearly met by the reactions in the study. However, MMP is not valid always. It is reliable for approximately $77 \%$ of the selected reactions and fails in case of the remaining reactions. It is observed that the majority of the reactions where the principle fails contain a hard base such as $\mathrm{OH}, \mathrm{F}, \mathrm{Cl}, \mathrm{N}$, etc. It is further noted that MEP is as convincing as MMP and proves to be valid for $77 \%$ of the reactions tested. MPP performs slightly better than MHP; however it is less suitable than MEP and MMP. MPP works for $50 \%$ of the reactions while MHP is applicable for $47 \%$ of the considered reactions. It is observed that the minimum magnetizability

Table 1. Computed frontier orbital energies $\left(E_{\mathrm{H}}\right.$ and $\left.E_{\mathrm{L}}\right)$, hardness $(\eta)$, electrophilicity index $(\omega)$, polarizability $(\alpha)$ and magnetizability $(\xi)$ values of the reactant and product molecules of the selected reactions using B3LYP/LanL2DZ method and their tabulated magnetizabilities $\left(\xi_{\mathrm{T}}\right)$ (in au)

\begin{tabular}{|c|c|c|c|c|c|c|c|c|}
\hline S. No. & Molecules & $E_{\mathrm{H}}$ & $E_{\mathrm{L}}$ & $\eta$ & $\omega$ & $\alpha$ & $\xi$ & $\xi_{\mathrm{T}}{ }^{[\mathrm{a}]}$ \\
\hline 1 & $\mathrm{H}_{2}$ & -0.429 & 0.116 & 0.272 & 0.045 & 2.013 & -0.588 & -1.145 \\
\hline 2 & $\mathrm{O}_{2}$ & -0.281 & -0.212 & 0.034 & 0.887 & 5.834 & 719.683 & 718.631 \\
\hline 3 & $\mathrm{H}_{2} \mathrm{O}_{2}$ & -0.266 & -0.030 & 0.118 & 0.093 & 9.738 & -2.523 & -3.641 \\
\hline 4 & $\mathrm{CO}$ & -0.382 & -0.059 & 0.161 & 0.151 & 9.890 & -1.030 & -2.062 \\
\hline 5 & $\mathrm{CO}_{2}$ & -0.298 & -0.071 & 0.113 & 0.149 & 17.215 & -0.120 & -4.419 \\
\hline 6 & $\mathrm{H}_{2} \mathrm{O}$ & -0.300 & 0.061 & 0.179 & 0.040 & 4.698 & -1.911 & -2.755 \\
\hline 7 & $\mathrm{CH}_{4}$ & -0.177 & -0.037 & 0.070 & 0.081 & 14.634 & -3.408 & -3.662 \\
\hline 8 & $\mathrm{Cl}_{2}$ & -0.331 & -0.199 & 0.066 & 0.529 & 13.712 & -6.890 & -8.502 \\
\hline 9 & $\mathrm{HCl}$ & -0.331 & 0.003 & 0.167 & 0.080 & 4.751 & -3.794 & -4.756 \\
\hline 10 & $\mathrm{H}_{2} \mathrm{~S}$ & -0.264 & 0.026 & 0.145 & 0.049 & 11.533 & -4.135 & -5.366 \\
\hline 11 & $\mathrm{~N}_{2}$ & -0.420 & -0.053 & 0.183 & 0.153 & 8.363 & -2.448 & -2.525 \\
\hline 12 & $\mathrm{NH}_{3}$ & -0.227 & 0.098 & 0.162 & 0.013 & 7.050 & -2.206 & - \\
\hline 13 & $\mathrm{NO}$ & -0.246 & -0.139 & 0.054 & 0.344 & 7.342 & 299.490 & 307.443 \\
\hline 14 & $\mathrm{HCN}$ & -0.373 & -0.007 & 0.183 & 0.098 & 11.917 & -1.602 & - \\
\hline 15 & $\mathrm{NO}_{2}$ & -0.312 & -0.136 & 0.088 & 0.285 & 13.776 & 22.419 & 31.565 \\
\hline 16 & $\mathrm{~N}_{2} \mathrm{O}_{4}$ & -0.351 & -0.139 & 0.106 & 0.283 & 32.779 & -4.207 & -4.839 \\
\hline 17 & $\mathrm{OH}$ & -0.339 & 0.058 & 0.198 & 0.050 & 3.329 & 10.493 & - \\
\hline 18 & $\mathrm{C}_{2} \mathrm{H}_{6}$ & -0.339 & 0.126 & 0.232 & 0.025 & 22.136 & -5.338 & -5.639 \\
\hline 19 & $\mathrm{C}_{3} \mathrm{H}_{8}$ & -0.323 & -0.125 & 0.099 & 0.254 & 32.538 & -4.428 & -8.122 \\
\hline 20 & $\mathrm{C}_{2} \mathrm{H}_{6} \mathrm{O}$ & -0.249 & 0.081 & 0.165 & 0.021 & 25.055 & -3.821 & -7.070 \\
\hline 21 & $\left(\mathrm{CH}_{3}\right)_{2} \mathrm{~S}$ & -0.219 & 0.038 & 0.129 & 0.032 & 36.373 & -5.720 & -9.448 \\
\hline 22 & $\mathrm{C}_{2} \mathrm{H}_{4}$ & -0.273 & -0.001 & 0.136 & 0.069 & 19.380 & -1.850 & -3.956 \\
\hline 23 & $\mathrm{C}_{2} \mathrm{H}_{2}$ & -0.212 & 0.111 & 0.161 & 0.008 & 18.424 & -2.029 & -4.377 \\
\hline 24 & $\mathrm{C}_{2} \mathrm{H}_{5} \mathrm{Cl}$ & -0.291 & 0.007 & 0.149 & 0.067 & 28.433 & -5.145 & - \\
\hline 25 & $\mathrm{Cl}_{2} \mathrm{CCH}_{2}$ & -0.279 & -0.032 & 0.123 & 0.098 & 34.821 & -8.833 & -10.353 \\
\hline 26 & $\mathrm{C}_{2} \mathrm{H}_{5} \mathrm{CN}$ & -0.332 & 0.020 & 0.176 & 0.069 & 33.637 & -5.485 & - \\
\hline 27 & $\left(\mathrm{CH}_{2} \mathrm{OH}\right)_{2}$ & -0.218 & 0.069 & 0.143 & 0.019 & 19.665 & -4.571 & -8.164 \\
\hline 28 & $\mathrm{CH}_{3} \mathrm{~F}$ & -0.343 & 0.060 & 0.201 & 0.050 & 11.571 & -1.695 & -3.745 \\
\hline 29 & $\mathrm{CHF}_{3}$ & -0.423 & 0.066 & 0.244 & 0.065 & 12.669 & -3.148 & - \\
\hline 30 & $\mathrm{CF}_{4}$ & -0.406 & -0.195 & 0.106 & 0.427 & 17.824 & -3.656 & - \\
\hline 31 & $\mathrm{~N}_{2} \mathrm{H}_{4}$ & -0.135 & 0.097 & 0.116 & 0.002 & 12.053 & -3.145 & -42.297 \\
\hline 32 & $\mathrm{CH}_{3} \mathrm{CHO}$ & -0.262 & -0.044 & 0.109 & 0.107 & 23.007 & -1.859 & -4.671 \\
\hline 33 & $\mathrm{C}_{6} \mathrm{H}_{6}$ & -0.253 & -0.009 & 0.122 & 0.070 & 54.838 & -6.692 & -11.531 \\
\hline 34 & $\mathrm{CH}_{3} \mathrm{OH}$ & -0.269 & 0.065 & 0.167 & 0.031 & 14.780 & -2.643 & -4.503 \\
\hline 35 & $\mathrm{C}_{6} \mathrm{H}_{5} \mathrm{OH}$ & -0.189 & -0.110 & 0.039 & 0.283 & 62.282 & -5.527 & -12.752 \\
\hline 36 & $\mathrm{C}_{6} \mathrm{H}_{5} \mathrm{NH}_{2}$ & -0.113 & -0.006 & 0.053 & 0.033 & 79.933 & -5.147 & -13.131 \\
\hline
\end{tabular}

[a] Data obtained from reference [36] and converted into atomic units (au). 1 au of $\xi=\mathrm{e}^{2} \mathrm{a}_{0}{ }^{2} / \mathrm{m}_{\mathrm{e}}=4.75209$ cgs-ppm. ${ }^{37}$ 
Table 2. Computed changes in the enthalpy $\left(\Delta_{\mathrm{f}} H^{0}\right)$ (at $\left.298 \mathrm{~K}_{\text {in }} \mathrm{kJ} \mathrm{mol}^{-1}\right)$, hardness $(\Delta \eta)$ (in au), electrophilicity index $(\Delta \omega)$ (in au), polarizability $(\Delta \alpha)$ (in au) and magnetizability $(\Delta \xi)$ (in au) along with MHP, MEP, MPP and MMP validity $(+)$ or invalidity $(-)$ for selected reactions

\begin{tabular}{|c|c|c|c|c|c|c|c|c|c|c|}
\hline S. No. & Reaction & $\Delta_{\mathrm{f}} H^{0[\mathrm{a}]}$ & $\Delta \eta$ & $+/-$ & $\Delta \omega$ & $+1-$ & $\Delta \alpha$ & $+/-$ & $\Delta \xi$ & $+/-$ \\
\hline 1 & $\mathrm{CO}_{2}+4 \mathrm{H}_{2} \rightarrow 2 \mathrm{H}_{2} \mathrm{O}+\mathrm{CH}_{4}$ & -148 & -0.774 & - & -0.168 & + & 1.237 & - & -4.756 & + \\
\hline 2 & $\mathrm{Cl}_{2}+\mathrm{H}_{2} \rightarrow 2 \mathrm{HCl}$ & -185 & -0.004 & - & -0.414 & + & 6.223 & - & -0.111 & + \\
\hline 3 & $3 \mathrm{H}_{2}+\mathrm{N}_{2} \rightarrow 2 \mathrm{NH}_{3}$ & -71 & -0.675 & - & -0.262 & + & 0.303 & - & -0.199 & + \\
\hline 4 & $2 \mathrm{NO} \rightarrow \mathrm{O}_{2}+\mathrm{N}_{2}$ & -180 & 0.110 & + & 0.352 & - & -0.487 & + & 118.256 & - \\
\hline 5 & $2 \mathrm{NO}+2 \mathrm{H}_{2} \rightarrow \mathrm{N}_{2}+2 \mathrm{H}_{2} \mathrm{O}$ & -647 & -0.111 & - & -0.545 & + & -0.951 & + & -604.072 & + \\
\hline 6 & $\mathrm{CH}_{4}+2 \mathrm{O}_{2} \rightarrow \mathrm{CO}_{2}+2 \mathrm{H}_{2} \mathrm{O}$ & -786 & 0.333 & + & -1.625 & + & -0.308 & + & -1439.901 & + \\
\hline 7 & $\mathrm{CO}+3 \mathrm{H}_{2} \rightarrow \mathrm{CH}_{4}+\mathrm{H}_{2} \mathrm{O}$ & -198 & -0.729 & - & -0.164 & + & 3.403 & - & -2.523 & + \\
\hline 8 & $2 \mathrm{NO}_{2} \rightarrow \mathrm{N}_{2} \mathrm{O}_{4}$ & -47 & -0.070 & - & -0.287 & + & -5.228 & + & -49.046 & + \\
\hline 9 & $2 \mathrm{C}_{2} \mathrm{H}_{2}+5 \mathrm{O}_{2} \rightarrow 4 \mathrm{CO}_{2}+2 \mathrm{H}_{2} \mathrm{O}$ & -2503 & 0.318 & + & -3.771 & + & -12.235 & + & -3598.660 & + \\
\hline 10 & $2 \mathrm{OH} \rightarrow \mathrm{H}_{2} \mathrm{O}_{2}$ & -213 & -0.279 & - & -0.006 & + & -3.080 & + & -23.509 & + \\
\hline 11 & $\mathrm{H}_{2} \mathrm{O}_{2} \rightarrow \mathrm{O}_{2}+\mathrm{H}_{2} \mathrm{O}$ & -98.5 & 0.078 & + & 0.390 & - & 2.123 & - & 360.454 & - \\
\hline 12 & $\mathrm{H}_{2} \mathrm{O}_{2}+\mathrm{Cl}_{2} \rightarrow \mathrm{O}_{2}+2 \mathrm{HCl}$ & -50 & 0.185 & + & 0.424 & - & -8.114 & + & 721.507 & - \\
\hline 13 & $4 \mathrm{NH}_{3}+5 \mathrm{O}_{2} \rightarrow 4 \mathrm{NO}+6 \mathrm{H}_{2} \mathrm{O}$ & -899 & 0.469 & + & -2.868 & + & -0.187 & + & -2403.099 & + \\
\hline 14 & $\mathrm{C}_{2} \mathrm{H}_{6}+\mathrm{O}_{2} \rightarrow\left(\mathrm{CH}_{3}\right)_{2} \mathrm{O}$ & -108.5 & -0.084 & - & -0.446 & + & -0.001 & + & -358.325 & + \\
\hline 15 & $\mathrm{C}_{2} \mathrm{H}_{2}+2 \mathrm{H}_{2} \rightarrow \mathrm{C}_{2} \mathrm{H}_{6}$ & -304 & -0.473 & - & -0.074 & + & 0.314 & - & -2.132 & + \\
\hline 16 & $\mathrm{C}_{2} \mathrm{H}_{4}+\mathrm{HCl} \rightarrow \mathrm{C}_{2} \mathrm{H}_{5} \mathrm{Cl}$ & -72 & -0.154 & - & -0.082 & + & 4.302 & - & 0.499 & - \\
\hline 17 & $\mathrm{C}_{2} \mathrm{H}_{2}+\mathrm{Cl}_{2} \rightarrow \mathrm{Cl}_{2} \mathrm{CCH}_{2}$ & -230 & -0.104 & - & -0.440 & + & -2.685 & + & 0.085 & - \\
\hline 18 & $\mathrm{HCN}+\mathrm{C}_{2} \mathrm{H}_{5} \mathrm{Cl} \rightarrow \mathrm{C}_{2} \mathrm{H}_{5} \mathrm{CN}+\mathrm{HCl}$ & -64 & 0.011 & + & -0.017 & + & -1.963 & + & -2.533 & + \\
\hline 19 & $\mathrm{C}_{2} \mathrm{H}_{6}+\mathrm{O}_{2} \rightarrow\left(\mathrm{CH}_{2} \mathrm{OH}\right)_{2}$ & -312 & -0.123 & - & -0.892 & + & 8.306 & - & -718.916 & + \\
\hline 20 & $\mathrm{C}_{3} \mathrm{H}_{8}+5 \mathrm{O}_{2} \rightarrow 3 \mathrm{CO}_{2}+4 \mathrm{H}_{2} \mathrm{O}$ & -2015 & 0.787 & + & -4.078 & + & 8.727 & - & -3601.992 & + \\
\hline 21 & $\mathrm{CH}_{3} \mathrm{~F}+\mathrm{CHF}_{3} \rightarrow \mathrm{CH}_{4}+\mathrm{CF}_{4}$ & -88 & -0.270 & - & 0.394 & - & -8.218 & + & -2.221 & + \\
\hline 22 & $\mathrm{~N}_{2} \mathrm{H}_{4}+\mathrm{O}_{2} \rightarrow \mathrm{N}_{2}+2 \mathrm{H}_{2} \mathrm{O}$ & -652 & 0.391 & + & -0.655 & + & 0.128 & - & -722.808 & + \\
\hline 23 & $\left(\mathrm{CH}_{3}\right)_{2} \mathrm{O}+\mathrm{H}_{2} \mathrm{~S} \rightarrow\left(\mathrm{CH}_{3}\right)_{2} \mathrm{~S}+\mathrm{H}_{2} \mathrm{O}$ & -73 & -0.003 & - & 0.002 & - & 4.484 & - & 0.325 & - \\
\hline 24 & $2 \mathrm{CH}_{3} \mathrm{OH}+3 \mathrm{O}_{2} \rightarrow 2 \mathrm{CO}_{2}+4 \mathrm{H}_{2} \mathrm{O}$ & -1321 & 0.507 & + & -2.262 & + & 6.158 & - & -2161.648 & + \\
\hline 25 & $\mathrm{C}_{2} \mathrm{H}_{5} \mathrm{OH}+3 \mathrm{O}_{2} \rightarrow 2 \mathrm{CO}_{2}+3 \mathrm{H}_{2} \mathrm{O}$ & -1306 & 0.496 & + & -2.262 & + & -5.966 & + & -2161.202 & + \\
\hline 26 & $\mathrm{C}_{2} \mathrm{H}_{5} \mathrm{OH}+\mathrm{Cl}_{2} \rightarrow \mathrm{CH}_{3} \mathrm{CHO}+2 \mathrm{HCl}$ & -53 & 0.212 & + & -0.283 & + & -6.258 & + & 1.263 & - \\
\hline 27 & $\mathrm{CH}_{3} \mathrm{CHO} \rightarrow \mathrm{CH}_{4}+\mathrm{CO}$ & -135 & 0.122 & + & 0.125 & - & 1.517 & - & -2.579 & + \\
\hline 28 & $\mathrm{C}_{6} \mathrm{H}_{5} \mathrm{OH}+\mathrm{H}_{2} \rightarrow \mathrm{C}_{6} \mathrm{H}_{6}+\mathrm{H}_{2} \mathrm{O}$ & -234 & -0.011 & - & -0.218 & + & 4.760 & - & -2.487 & + \\
\hline 29 & $2 \mathrm{C}_{6} \mathrm{H}_{6}+15 \mathrm{O}_{2} \rightarrow 12 \mathrm{CO}_{2}+6 \mathrm{H}_{2} \mathrm{O}$ & -6309 & 1.679 & + & -11.406 & + & -37.574 & + & -10794.771 & + \\
\hline 30 & $\mathrm{C}_{6} \mathrm{H}_{5} \mathrm{NH}_{2}+\mathrm{H}_{2} \rightarrow \mathrm{C}_{6} \mathrm{H}_{6}+\mathrm{NH}_{3}$ & -86 & -0.041 & - & 0.005 & - & 20.058 & - & -3.162 & + \\
\hline
\end{tabular}

[a] Computed by taking energies of atomization from reference [35].

principle is almost as valuable as minimum electrophilicity principle in predicting the direction of a reaction. The sign of $\Delta \xi$ can be used to provide an indication for higher stability of products thermodynamically.

In order to understand the significance of the results, a brief statistical analysis is performed for each parameter with respect to $\Delta_{\mathrm{f}} H^{0}$. Our study is based on the stability criterion, i.e. minimum energy condition, thus it is important to validate the correlation of $\Delta_{\mathrm{f}} H^{0}$ with these descriptors. Regression analysis has been performed for this purpose. An attempt to explore the relationship of $\Delta \alpha$ with $\Delta_{\mathrm{f}} H^{0}$ is futile $\left(R^{2}=0.4871, R=+0.70, p=0.001\right)$, although $\Delta \eta$ is found to follow a satisfactory linear relation with $\Delta_{\mathrm{f}} H^{0}\left(R^{2}=0.6266, R=-0.79, p=0.001\right)$. Lower values of $R^{2}$ denote inferior correlation of $\Delta \alpha$ and $\Delta \eta$ with $\Delta_{\mathrm{f}} H^{0}$ whereas $p$-values indicate that the result is significant. It can be inferred that MPP and MHP may not always follow the minimum energy criterion and may become invalid in several cases. An analysis of $\Delta \xi$ and $\Delta \omega$ with $\Delta_{\mathrm{f}} H^{0}$ presents an excellent relationship. For $\Delta \xi$ and $\Delta_{\mathrm{f}} H^{0}, R^{2}=0.9792, R$ $=+0.99$ and $p=0.001$ while $R^{2}=0.9679, R=+0.98$ and $p$
$=0.001$ for $\Delta \omega$ and $\Delta_{\mathrm{f}} H^{0}$. Such high values of $R^{2}$ clearly signify the outstanding correlation between the parameters. Further, a perfect positive correlation is presented for $\Delta \xi$ and $\Delta_{\mathrm{f}} H^{0}$. Significance of the correlation is highlighted by the $p$-values. It is concluded that MMP as well as MEP are highly related to $\Delta_{\mathrm{f}} H^{0}$ and thus follow the minimum energy and high stability condition. As the validity of minimum energy principle increases, MMP and MEP become valid as well.

The cube-roots of exact polarizability $\Delta \alpha^{1 / 3}=\sum_{j} a_{j} \alpha_{j}^{1 / 3}$ have been proved to be more useful in comparison to $\Delta \alpha$ to predict the direction of a chemical reaction. ${ }^{35}$ Hence, following the above notion, we have determined the cube-roots for hardness, electrophilicity index, polarizability as well as magnetizability and these are presented in Table 3. It is apparent from the outcomes that the validity of MHP as well as MPP increases when their cube-roots are considered. In fact, the soundness of MHP increases drastically as compared to MPP. As expected, these results indicate efficiency of cube-roots of hardness and polarizability in predicting the path followed by a reaction. Although in 
comparison to other principles, MHP and MPP still remain the least accurate for the reactions considered in the present study and have no predictive value. Conversely, the validity of MEP and MMP is found to be decreased in this case. As evident from Table 3, a decrease in the validity of MMP takes place when the cube-roots of magnetizability are considered. However MMP is still valid for several reactions $\left(\Delta \xi^{1 / 3}<0\right)$ and performs remarkably in contrast to MHP and MPP. As a result, it appears that $\Delta \xi^{1 / 3}$ is more or less as reliable as $\Delta \xi$. It is further observed that MEP is the most the convincing of all principles considering its high validity in both the cases. Next, $\Delta_{\mathrm{f}} H^{0}$ demonstrates an excellent linear relationship with $\Delta \xi^{1 / 3}\left(R^{2}=0.9818\right)$ and $\Delta \omega^{1 / 3}\left(R^{2}=0.8916\right)$ but poor connections are found with $\Delta \eta^{1 / 3}\left(R^{2}=0.5530\right)$ or $\Delta \alpha^{1 / 3}\left(R^{2}=0.5338\right)$.

We have tried to accommodate reactions with different types of molecules, viz. inorganic, aliphatic and aromatic, in the present study to consider as many chemical effects as possible. Although for further studies it is suggested that the validity of this principle should be assessed in case of other reaction classes as well.

\section{Conclusion}

We have tried to validate Minimum Magnetizability Principle employing 30 elementary chemical reactions. Change in the magnetizability $(\Delta \xi)$ and its cube-root $\left(\Delta \xi^{1 / 3}\right)$ is computed in order to check the applicability of the principle in determining the direction of the reaction as well as stability of the products. We have also calculated change in hardness $(\Delta \eta)$, electrophilicity index $(\Delta \omega)$, polarizability $(\Delta \alpha)$ and their cube-roots $\left(\Delta \eta^{1 / 3}, \Delta \omega^{1 / 3}\right.$, $\Delta \alpha^{1 / 3}$ ) in order to make a comparative study. It is observed that the Minimum Magnetizability Principle is valid for chemical reactions however with some limitations. The principle fails to work in the presence of hard species. Minimum Electrophilicity Principle and Minimum Magnetizability Principle are found to have comparable reliability followed by Minimum Polarizability Principle, however Maximum Hardness Principle appears to be less valid for the chosen reactions. In conclusion, Minimum Magnetizability Principle is found to be fairly valid for reactions and can be successfully employed solely or in

Table 3. Computed changes in the enthalpy $\left(\Delta_{\mathrm{f}} H^{0}\right)$ (at $298 \mathrm{~K}$ in $\mathrm{kJ} \mathrm{mol}{ }^{-1}$ ), cube-root of hardness $\left(\Delta \eta^{1 / 3}\right.$ ) (in au), cube-root of electrophilicity index $\left(\Delta \omega^{1 / 3}\right)$ (in au), cube-root of polarizability $\left(\Delta \alpha^{1 / 3}\right)$ (in au) and cube-root of magnetizability $\left(\Delta \xi^{1 / 3}\right)$ (in au) along with MHP, MEP, MPP and MMP validity $(+)$ or invalidity $(-)$ for selected reactions

\begin{tabular}{|c|c|c|c|c|c|c|c|c|c|c|}
\hline S. No. & Reaction & $\Delta_{\mathrm{f}} H^{0[\mathrm{a}]}$ & $\Delta \eta^{1 / 3}$ & $+1-$ & $\Delta \omega^{1 / 3}$ & $+/-$ & $\Delta \alpha^{1 / 3}$ & $+/-$ & $\Delta \xi^{1 / 3}$ & $+/-$ \\
\hline 1 & $\mathrm{CO}_{2}+4 \mathrm{H}_{2} \rightarrow 2 \mathrm{H}_{2} \mathrm{O}+\mathrm{CH}_{4}$ & -148 & -1.537 & - & -0.836 & + & -1.837 & + & -0.142 & + \\
\hline 2 & $\mathrm{Cl}_{2}+\mathrm{H}_{2} \rightarrow 2 \mathrm{HCl}$ & -185 & 0.049 & + & -0.302 & + & -0.294 & + & -0.379 & + \\
\hline 3 & $3 \mathrm{H}_{2}+\mathrm{N}_{2} \rightarrow 2 \mathrm{NH}_{3}$ & -71 & -1.421 & - & -1.133 & + & -1.983 & + & 1.258 & - \\
\hline 4 & $2 \mathrm{NO} \rightarrow \mathrm{O}_{2}+\mathrm{N}_{2}$ & -180 & 0.137 & + & 0.094 & - & -0.057 & + & -5.767 & + \\
\hline 5 & $2 \mathrm{NO}+2 \mathrm{H}_{2} \rightarrow \mathrm{N}_{2}+2 \mathrm{H}_{2} \mathrm{O}$ & -647 & -0.356 & - & -0.894 & + & -1.033 & + & -15.535 & + \\
\hline 6 & $\mathrm{CH}_{4}+2 \mathrm{O}_{2} \rightarrow \mathrm{CO}_{2}+2 \mathrm{H}_{2} \mathrm{O}$ & -786 & 0.550 & + & -1.139 & + & -0.115 & + & -19.393 & + \\
\hline 7 & $\mathrm{CO}+3 \mathrm{H}_{2} \rightarrow \mathrm{CH}_{4}+\mathrm{H}_{2} \mathrm{O}$ & -198 & -1.513 & - & -0.824 & + & -1.814 & + & 0.778 & - \\
\hline 8 & $2 \mathrm{NO}_{2} \rightarrow \mathrm{N}_{2} \mathrm{O}_{4}$ & -47 & -0.417 & - & -0.659 & + & -1.594 & + & -7.254 & + \\
\hline 9 & $2 \mathrm{C}_{2} \mathrm{H}_{2}+5 \mathrm{O}_{2} \rightarrow 4 \mathrm{CO}_{2}+2 \mathrm{H}_{2} \mathrm{O}$ & -2503 & 0.352 & + & -2.393 & + & -0.606 & + & -46.730 & + \\
\hline 10 & $2 \mathrm{OH} \rightarrow \mathrm{H}_{2} \mathrm{O}_{2}$ & -213 & -0.676 & - & -0.282 & + & -0.851 & + & -5.740 & + \\
\hline 11 & $\mathrm{H}_{2} \mathrm{O}_{2} \rightarrow \mathrm{O}_{2}+\mathrm{H}_{2} \mathrm{O}$ & -98.5 & 0.236 & + & 0.369 & - & 0.439 & - & 4.601 & - \\
\hline 12 & $\mathrm{H}_{2} \mathrm{O}_{2}+\mathrm{Cl}_{2} \rightarrow \mathrm{O}_{2}+2 \mathrm{HCl}$ & -50 & 0.532 & + & 0.561 & - & 0.633 & - & 9.106 & - \\
\hline 13 & $4 \mathrm{NH}_{3}+5 \mathrm{O}_{2} \rightarrow 4 \mathrm{NO}+6 \mathrm{H}_{2} \mathrm{O}$ & -899 & 1.087 & + & -0.885 & + & 1.152 & - & -20.284 & + \\
\hline 14 & $\mathrm{C}_{2} \mathrm{H}_{6}+\mathrm{O}_{2} \rightarrow\left(\mathrm{CH}_{3}\right)_{2} \mathrm{O}$ & -108.5 & -0.229 & - & -0.493 & + & -0.782 & + & -4.296 & + \\
\hline 15 & $\mathrm{C}_{2} \mathrm{H}_{2}+2 \mathrm{H}_{2} \rightarrow \mathrm{C}_{2} \mathrm{H}_{6}$ & -304 & -1.226 & - & -0.620 & + & -2.359 & + & 1.194 & - \\
\hline 16 & $\mathrm{C}_{2} \mathrm{H}_{4}+\mathrm{HCl} \rightarrow \mathrm{C}_{2} \mathrm{H}_{5} \mathrm{Cl}$ & -72 & -0.535 & - & -0.434 & + & -1.315 & + & 1.061 & - \\
\hline 17 & $\mathrm{C}_{2} \mathrm{H}_{2}+\mathrm{Cl}_{2} \rightarrow \mathrm{Cl}_{2} \mathrm{CCH}_{2}$ & -230 & -0.451 & - & -0.547 & + & -1.769 & + & 1.102 & - \\
\hline 18 & $\mathrm{HCN}+\mathrm{C}_{2} \mathrm{H}_{5} \mathrm{Cl} \rightarrow \mathrm{C}_{2} \mathrm{H}_{5} \mathrm{CN}+\mathrm{HCl}$ & -64 & 0.013 & + & -0.028 & + & -0.427 & + & -0.427 & + \\
\hline 19 & $\mathrm{C}_{2} \mathrm{H}_{6}+\mathrm{O}_{2} \rightarrow\left(\mathrm{CH}_{2} \mathrm{OH}\right)_{2}$ & -312 & -0.416 & - & -0.983 & + & -2.583 & + & -8.873 & + \\
\hline 20 & $\mathrm{C}_{3} \mathrm{H}_{8}+5 \mathrm{O}_{2} \rightarrow 3 \mathrm{CO}_{2}+4 \mathrm{H}_{2} \mathrm{O}$ & -2015 & 1.622 & + & -2.475 & + & 2.252 & - & -49.609 & - \\
\hline 21 & $\mathrm{CH}_{3} \mathrm{~F}+\mathrm{CHF}_{3} \rightarrow \mathrm{CH}_{4}+\mathrm{CF}_{4}$ & -88 & -0.327 & - & 0.416 & - & 0.465 & - & -0.387 & + \\
\hline 22 & $\mathrm{~N}_{2} \mathrm{H}_{4}+\mathrm{O}_{2} \rightarrow \mathrm{N}_{2}+2 \mathrm{H}_{2} \mathrm{O}$ & -652 & 0.883 & + & 0.144 & - & 1.286 & - & -11.326 & + \\
\hline 23 & $\left(\mathrm{CH}_{3}\right)_{2} \mathrm{O}+\mathrm{H}_{2} \mathrm{~S} \rightarrow\left(\mathrm{CH}_{3}\right)_{2} \mathrm{~S}+\mathrm{H}_{2} \mathrm{O}$ & -73 & -0.006 & - & 0.016 & - & -0.197 & + & 0.139 & - \\
\hline 24 & $2 \mathrm{CH}_{3} \mathrm{OH}+3 \mathrm{O}_{2} \rightarrow 2 \mathrm{CO}_{2}+4 \mathrm{H}_{2} \mathrm{O}$ & -1321 & 1.148 & + & -1.080 & + & 1.555 & - & -30.069 & + \\
\hline 25 & $\mathrm{C}_{2} \mathrm{H}_{5} \mathrm{OH}+3 \mathrm{O}_{2} \rightarrow 2 \mathrm{CO}_{2}+3 \mathrm{H}_{2} \mathrm{O}$ & -1306 & 1.137 & + & -1.072 & + & 1.862 & - & -30.030 & - \\
\hline 26 & $\mathrm{C}_{2} \mathrm{H}_{5} \mathrm{OH}+\mathrm{Cl}_{2} \rightarrow \mathrm{CH}_{3} \mathrm{CHO}+2 \mathrm{HCl}$ & -53 & 0.627 & + & 0.251 & - & 0.887 & - & -0.883 & + \\
\hline 27 & $\mathrm{CH}_{3} \mathrm{CHO} \rightarrow \mathrm{CH}_{4}+\mathrm{CO}$ & -135 & 0.478 & + & 0.490 & - & 1.748 & - & -1.285 & + \\
\hline 28 & $\mathrm{C}_{6} \mathrm{H}_{5} \mathrm{OH}+\mathrm{H}_{2} \rightarrow \mathrm{C}_{6} \mathrm{H}_{6}+\mathrm{H}_{2} \mathrm{O}$ & -234 & 0.071 & + & -0.257 & + & 0.248 & - & -0.519 & + \\
\hline 29 & $2 \mathrm{C}_{6} \mathrm{H}_{6}+15 \mathrm{O}_{2} \rightarrow 12 \mathrm{CO}_{2}+6 \mathrm{H}_{2} \mathrm{O}$ & -6309 & 3.330 & + & -6.815 & + & 6.432 & - & -144.017 & + \\
\hline 30 & $\mathrm{C}_{6} \mathrm{H}_{5} \mathrm{NH}_{2}+\mathrm{H}_{2} \rightarrow \mathrm{C}_{6} \mathrm{H}_{6}+\mathrm{NH}_{3}$ & -86 & 0.018 & + & -0.030 & + & 0.146 & - & -0.622 & + \\
\hline
\end{tabular}

[a] Computed by taking energies of atomization from reference [35]. 
conjunction with other principles for theoretical as well as practical applications.

\section{Author Contributions}

Hiteshi Tandon: Conceptualization, Methodology, Software, Resources, Formal analysis, Validation, Investigation, Writing - Original Draft, Visualization. Tanmoy Chakraborty: Conceptualization, Supervision, Writing Review \& Editing. Vandana Suhag: Supervision, Writing - Review \& Editing.

\section{Conflicts Of Interest}

The authors declare no conflicts of interest.

\section{Funding}

This research did not receive any specific grant from funding agencies in the public, commercial, or not-for-profit sectors.

\section{Acknowledgements}

Dr. Tanmoy Chakraborty is thankful to Sharda University and Dr. Hiteshi Tandon is thankful to Manipal University Jaipur for providing computational resources and research facility.

\section{References}

1. P. Geerlings, F. De Proft, W. Langenaeker, Chem. Rev. 2003, 103, 1793-1874. DOI:10.1021/cr990029p

2. R. G. Parr, R. G. Pearson, J. Am. Chem. Soc. 1983, 105, 75127516. DOI:10.1021/ja00364a005

3. R. G. Parr, L. von Szentpaly, S. Liu, J. Am. Chem. Soc. 1999, 121, 1922-1924. DOI:10.1021/ja983494x

4. H. Tandon, T. Chakraborty, V. Suhag, J. Struct. Chem. 2019, 60, 1725-1734. DOI:10.1134/S0022476619110040

5. H. Tandon, T. Chakraborty, V. Suhag, J. Math. Chem. 2020, 58, 2188-2196. DOI:10.1007/s10910-020-01176-5

6. P. Yadav, H. Tandon, B. Malik, T. Chakraborty, J. Chem. Res. 2020. DOI:10.1177/1747519820937272

7. H. Tandon, T. Chakraborty, V. Suhag, J. Math. Chem. 2019, 57, 2142-2153. DOI:10.1007/s10910-019-01055-8

8. P. Dahle, K. Ruud, T. Helgaker, P. R. Taylor, in: Z. B. Maksid, W. J. Orville-Thomas (Eds.): Theoretical and Computational Chemistry, Vol. 6, Elsevier, Amsterdam, 1999, pp. 147-188. DOI:10.1016/S1380-7323(99)80008-9

9. P. K. Chattaraj, S. Giri, J. Phys. Chem. A, 2007, 111, 1111611121. DOI:10.1021/jp0760758

10. P. F. Provasi, G. I. Pagola, M. B. Ferraro, S. Pelloni, P. Lazzeretti, J. Phys. Chem. A 2014, 118, 6333-6342.

DOI:10.1021/jp408969k

11. C. Foroutan-Nejad, Theor. Chem. Acc. 2015, 134, 8.

\section{DOI:10.1007/s00214-015-1617-7}

12. N. Zarycz, P. F. Provasi, G. I. Pagola, M. B. Ferraro, S. Pelloni, P. Lazzeretti, J. Comput. Chem. 2016, 37, 1552-1558. DOI:10.1002/jcc.24369

13. S. Pelloni, P. F. Provasi, G. I. Pagola, M. B. Ferraro, P. Lazzeretti, J. Phys. Chem. A 2017, 121, 9369-9376.

DOI:10.1021/acs.jpca.7b09104

14. T. Janda, C. Foroutan-Nejad, ChemPhysChem 2018, 19, 2357-2363. DOI:10.1002/cphc.201800364

15. M. Khatua, U. Sarkar, P. K. Chattaraj, Int. J. Quantum Chem. 2015, 115, 144-157. DOI:10.1002/qua.24801

16. R. Das, A. Chakraborty, S. Pan, P. K. Chattaraj, Curr. Org. Chem. 2013, 17, 2831-2844.

\section{DOI: $10.2174 / 13852728113179990129$}

17. B. J. Tefft, S. Uthamaraj, J. J. Harburn, O. Hlinomaz, A. Lerman, D. Dragomir-Daescu, G. S. Sandhu, J. Magn. Magn. Mater. 2017, 427, 100-104. DOI:10.1016/j.jmmm.2016.11.007

18. C. Carretero, I. Lope, J. Acero, IEEE J. Emerg. Sel. Topics Power Electron. 2019. DOI:10.1109/JESTPE.2019.2935226

19. D. I. Merkulov, A. V. Muravlev, E. D. Martynova, D. A. Pelevina, V. A. Turkov, V. A. Naletova, J. Magn. Magn. Mater. 2019, 470, 81-84. DOI:10.1016/j.jmmm.2018.02.038

20. M. A. Alheety, A. Raoof, S. A. Al-Jibori, A. Karadağ, A. I. Khaleel, H. Akbaş, O. Uzun, Mater. Chem. Phys. 2019, 231, 292-300. DOI:10.1016/j.matchemphys.2019.04.040

21. C. Gholve, S. Banerjee, S. Kulkarni, J. Radioanal. Nucl. Chem. 2020, 323, 1041-1046. DOI:10.1007/s10967-020-07023-w

22. R. G. Pearson, J. Chem. Educ. 1987, 64, 561-567. DOI:10.1021/ed064p561

23. P. K. Chattaraj, S. Sengupta, J. Phys. Chem. 1996, 100, 1612616130. DOI:10.1021/jp961096f

24. S. Noorizadeh, Chin. J. Chem., 2007, 25, 1439-1444. DOI:10.1002/cjoc.200790266

25. P. K. Chattaraj, P. Fuentealba, B. Gomez, R. Contreras, J. Am. Chem. Soc. 2000, 122, 348-351. DOI:10.1021/ja992337a

26. F. A. Pasha, H. K. Srivastava, P. P. Singh, Int. J. Quantum Chem. 2005, 104, 87-100. DOI:10.1002/qua.20569

27. Y. L. Zhang, Z. Z. Yang, Int. J. Quantum Chem. 2006, 106, 1723-1735. DOI:10.1002/qua.20952

28. P. Selvarengan, P. Kolandaivel, J. Mol. Struct. (Theochem) 2004, 671, 77-86. DOI:10.1016/j.theochem.2003.10.021

29. K. Anandan, P. Kolandaivel, R. Kumaresan, Int. J. Quantum Chem. 2005, 104, 286-298. DOI:10.1002/qua.20559

30. S. Noorizadeh, J. Mol. Struct. (Theochem) 2005, 713, 27-32. DOI:10.1016/j.theochem.2004.09.029

31. A. Tanwar, S. Pal, D. R. Roy, P. K. Chattaraj, J. Chem. Phys. 2006, 125, 056101. DOI:10.1063/1.2227381

32. J. F. Janak, Phys. Rev. B 1978, 18, 7165-7168. DOI:10.1103/PhysRevB.18.7165

33. T. A. Keith, R. F. W. Bader, Chem. Phys. Lett. 1993, 210, 223 231. DOI:10.1016/0009-2614(93)89127-4

34. M. J. Frisch, G. W. Trucks, H. B. Schlegel, G. E. Scuseria, M. A. Robb, J. R. Cheeseman, J. A. Montgomery, Jr., T. Vreven, K. N. Kudin, J. C. Burant, J. M. Millam, S. S. Iyengar, J. Tomasi, V. Barone, B. Mennucci, M. Cossi, G. Scalmani, N. Rega, G. A. Petersson, H. Nakatsuji, M. Hada, M. Ehara, K. Toyota, 
R. Fukuda, J. Hasegawa, M. Ishida, T. Nakajima, Y. Honda, O. Kitao, H. Nakai, M. Klene, X. Li, J. E. Knox, H. P. Hratchian, J. B. Cross, C. Adamo, J. Jaramillo, R. Gomperts, R. E. Stratmann, O. Yazyev, A. J. Austin, R. Cammi, C. Pomelli, J. W. Ochterski, P. Y. Ayala, K. Morokuma, G. A. Voth, P. Salvador, J. J. Dannenberg, V. G. Zakrzewski, S. Dapprich, A. D. Daniels, M. C. Strain, O. Farkas, D. K. Malick, A. D. Rabuck, K. Raghavachari, J. B. Foresman, J. V. Ortiz, Q. Cui, A. G. Baboul, S. Clifford, J. Cioslowski, B. B. Stefanov, G. Liu, A. Liashenko, P. Piskorz, I. Komaromi, R. L. Martin, D. J. Fox, T. Keith, M. A. Al-Laham, C. Y. Peng, A. Nanayakkara, M.
Challacombe, P. M. W. Gill, B. Johnson, W. Chen, M. W. Wong, C. Gonzalez, J. A. Pople, Gaussian 03, Revision C.01. Gaussian, Inc., Wallingford CT, 2004.

35. U. Hohm, J. Phys. Chem. A 2000, 104, 8418-8423. DOI:10.1021/jp0014061

36. W. M. Haynes (Ed.), CRC Handbook of Chemistry and Physics, Vol. 97, CRC Press, Boca Raton, FL, 2017.

37. E. Steiner, P. W. Fowler, in: B. Grimm, R. J. Porra, W. Rüdiger, H. Scheer (Eds.): Chlorophylls and Bacteriochlorophylls: Biochemistry, Biophysics, Functions and Applications, Springer, Netherlands, 2006, pp. 337-347.

\section{Povzetek}

Novo načelo, znano kot načelo minimalne magnetizabilnosti, je bilo nedavno predstavljeno v okviru teorije gostotnega funkcionala (DFT). Da bi potrdili to načelo, smo na ravni teorije B3LYP/LanL2DZ izračunali spremembe v magnetizabilnosti $(\Delta \xi)$ in tretjem korenu iz $\Delta \xi\left(\Delta \xi^{1 / 3}\right)$ za nekatere osnovne kemijske reakcije. Ugotovili smo, da načelo velja za $77 \%$ preučevanih reakcij. Opazili smo, da so molekule $z$ najnižjo vsoto $\xi$ ali $\xi^{1 / 3}$ na splošno najbolj stabilne. Načelo ne deluje v prisotnosti trdih zvrsti. Izvedli smo tudi primerjalno študijo s spreminjanjem trdote $(\Delta \eta)$, indeksa elektrofilnosti $(\Delta \omega)$, polarizabilnosti $(\Delta \alpha)$ in njihovih tretjih korenov $\left(\Delta \eta^{1 / 3}, \Delta \omega^{1 / 3}, \Delta \alpha^{1 / 3}\right)$. Opazili smo, da je načelo minimalne magnetizabilnosti skoraj tako zanesljivo kot načelo minimalne elektrofilnosti. Zdi se, da bi to načelo lahko pomagalo pri napovedovanju smeri različnih reakcij in stabilnih geometrijskih ureditev.

Except when otherwise noted, articles in this journal are published under the terms and conditions of the Creative Commons Attribution 4.0 International License 